\title{
ANALIZA SPOSOBÓW OGRANICZANIA BARIER DETERMINUJACCYCH ROZWÓJ MAŁEJ FIRMY PRODUKCYJNEJ
}

\begin{abstract}
Małe przedsiębiorstwa przyczyniają się do aktywizacji siły roboczej na miarę regionu. Ich rolą jest również pobudzanie przedsiębiorczości, przez co przyczyniają się do zmniejszenia poziomu bezrobocia. Aktywność takich podmiotów wpływa na pojawienie się dalszych inicjatyw gospodarczych. Działalność małych firm pobudza konkurencyjność regionu i rozszerza zakres inwestycji w regionie. Poza tym, działalność małych przedsiębiorstw pozostaje źródłem dochodów do budżetów regionalnych, co może zostać przeznaczone na cele rozwojowe tego regionu. Trzeba też wspomnieć, że małe firmy (w tym wyszczególnione w tytule artykułu firmy produkcyjne) pobudzają władze samorządowe do działania na rzecz rozwoju regionu.

Problematyka barier rozwoju małych przedsiębiorstw, w tym produkcyjnych, wymaga poświęcenia temu tematowi większej uwagi ze względu na aktualność tego problemu w polskiej gospodarce, a także konieczność podjęcia działań umożliwiających minimalizowanie tych barier .Dotychczasowa praktyka analizy barier małych firm skłania do sformułowania następujących pytań: Jakie są czynniki determinujące rozwój małych przedsiębiorstw, w tym produkcyjnych? W jaki sposób można te bariery przezwyciężać?

Podjęcie działań podejmowanych w celu przezwyciężenia barier niesie ze sobą liczne dylematy, a nieraz także i pewne ryzyko. Celem artykułu jest analiza sposobów ograniczania barier determinujących rozwój małej firmy produkcyjnej. Jako przykład wykorzystano firmę Pro-Art.
\end{abstract}

\footnotetext{
${ }^{1}$ Dr Agnieszka Rzepka, Katedra Ekonomii i Zarządzania Gospodarką, Wydział Zarządzania, Politechnika Lubelska, ul. Nadbystrzycka 38, 20-618 Lublin; e-mail: a.rzepka@pollub.pl (autor korespondencyjny).

Agnieszka Rzepka, PhD, Faculty of Management, Lublin University of Technology, Nadbystrzycka 38, 20-618 Lublin; e-mail: a.rzepka@ pollub.pl (corresponding author).

2 Prof. dr hab. Ewa Bojar, Katedra Ekonomii i Zarządzania Gospodarką, Wydział Zarządzania, Politechnika Lubelska; e-mail: e.bojar@pollub.pl.

Ewa Bojar, Prof., DSc, PhD, Faculty of Management, Lublin University of Technology, Nadbystrzycka 38, Lublin; e-mail: e.bojar@ pollub.pl.

${ }^{3}$ Prof. dr hab. Zbigniew Olesiński, Akademia Finansów i Biznesu Vistula, Stokłosy 3, 02-787 Warszawa; e-mail: zbigniew_olesinski@op.pl.

Zbigniew Olesiński, Prof., DSc, PhD, Vistula University, Stokłosy 3, 02-787 Warszawa; e-mail: zbigniew_olesinski@op.pl.
} 
W Polsce wciąż niewiele jest badań na temat skutecznych sposobów niwelowania barier rozwoju małych firm, zwłaszcza o profilu produkcyjnym. Niedostateczna jest także wiedza w zakresie doskonalenia tych procesów.

Słowa kluczowe: bariery, rozwój, małe i średnie przedsiębiorstwa.

\section{WPROWADZENIE}

Małe przedsiębiorstwa produkcyjne pełnią niezwykle istotną rolę w polskiej gospodarce. Mają znaczenie nie tylko w wymiarze gospodarczym, ale i społecznym. Ważne znaczenie przypisuje się małym przedsiębiorstwom w kontekście rozwoju regionalnego, z uwagi na znaczny wpływ tego sektora na poziom zatrudnienia, wielkość wyprodukowanych towarów, wysokość uzyskanych dochodów.

Niemniej jednak małe firmy natrafiają w rzeczywistości gospodarczej na wiele problemów: brak szans w konkurencji z dużymi podmiotami, borykają się z niekorzystnym systemem finansowym, brak im odpowiednich funduszy na rozwój, nie posiadają skutecznej reklamy i promocji. Nie potrafią skutecznie aplikować o fundusze z Unii Europejskiej. Trudność sprawia im napisanie biznesplanów. Często także personel takiej firmy nie posiada odpowiednich kwalifikacji. Zatrudnieni w małej firmie nierzadko nie dostrzegają szans, jakie niesie wykorzystanie Internetu w działalności gospodarczej.

\section{POJECIE MAŁEJ FIRMY PRODUKCYJNEJ}

Do tej pory nie istniała żadna definicja małej firmy. Najczęściej za kryterium małej firmy przyjmowano jako miernik wielkości liczbę zatrudnionych (nie więcej niż 5 osób) i wielkość obrotów (nie więcej niż 400000 EURO). Od 1 stycznia 2001 roku obowiązuje ustawa Prawo o działalności gospodarczej. Po raz pierwszy ustawowo określono w niej pojęcie małej firmy. W ustawie przyjęto, że o zaliczeniu firmy do kategorii małych firm decydują trzy kryteria:

1) średnioroczne zatrudnienie (nie więcej niż 50 pracowników),

2) wysokość osiągniętych przychodów netto ze sprzedaży wyrobów, usług i operacji finansowych (nie więcej niż $7 \mathrm{mln}$ EURO) lub suma aktywów bilansu sporządzonego na koniec roku obrotowego (nie więcej niż 5 mln EURO),

3) udział innych przedsiębiorstw (nie małych) we wkładach, udziałach, akcjach, zyskach lub głosach nie może przekraczać $25 \%$. Niestety, przyjęte przez ustawodawcę kwoty pozostają dla ponad $90 \%$ małych firm wielkościami nieosiągalnymi. Można stwierdzić, że takie ,szerokie” określenie małych firm miało zapewnić większym podmiotom dostęp do europejskich funduszy pomocowych, przeznaczonych dla przedsiębiorstw małych. Równocześnie w ustawie nie podano definicji mikrofirmy (przedsiębiorstwa), mimo że większość firm w Polsce to firmy mikro zatrudniające do 9 pracowników ${ }^{4}$.

W roku 2010 małe i mikroprzedsiębiorstwa tworzyły 55,5\% PKB wytwarzanego przez polskie firmy. Było w nich zatrudnionych, włączając szarą strefę, niemal 50\% obywateli

\footnotetext{
${ }^{4}$ H. Bieniok (red.), Przedsiębiorczość, konkurencyjność oraz kondycja małych i średnich przedsiębiorstw w obliczu integracji z. Unia Europejska, Katowice 2003, s. 163.
} 
polskich, pracujących w sektorze rynkowym ${ }^{5}$. Po 1989 roku nastąpiło wiele zmian w życiu gospodarczym. Zmiany te dotknęły także i małe przedsiębiorstwa. Przede wszystkim wzrosła ich liczba, powstawały one masowo jako zakłady osób fizycznych (92\%) lub też spółek cywilnych (8\%). Obecnie liczba małych firm osiągnęła poziom ok. 1,8 mln. Można też zaobserwować następujący trend: tendencję do zmniejszania się ich liczby. Przyczyną może być wyrejestrowanie bądź częściej zawieszanie działalności. Takie zjawisko jest wysoce niekorzystne dla gospodarki polskiej. Trzeba pamiętać, że małe firmy są postrzegane jako jedyne podmioty mogące wchłonąć rzeszę bezrobotnych powstałą wskutek racjonalizacji zamienienia, restrukturyzacji oraz koncentracji organizacyjnej firm średnich i dużych ${ }^{6}$.

Część z tych firm to firmy produkcyjne. W literaturze nie można znaleźć stricte definicji „firmy produkcyjnej”. Jako przedsiębiorstwo produkcyjne najczęściej przyjmuje się definicje, iż jest to podmiot, którego celem jest wytwarzanie określonych dóbr materialnych, przynoszących zyski producentowi i zaspokajających potrzeby społeczne. Natomiast produkcja wyrobów jest to działalność polegająca na wydobywaniu surowców mineralnych bądź przetwarzaniu surowców i materiałów na wyroby gotowe ${ }^{7}$. Firma produkcyjna zajmuje się wytwarzaniem dóbr użytkowych dla zaspokojenia popytu konsumentów. Wyróżnia się wiele jej typów (por. tabela 1).

Tabela 1. Typy przedsiębiorstw produkcyjnych

\begin{tabular}{|l|l|}
\hline \multicolumn{1}{|c|}{ Kryterium } & \multicolumn{1}{|c|}{ Rodzaje } \\
\hline $\begin{array}{l}\text { Ze względu na } \\
\text { cele }\end{array}$ & $\begin{array}{l}\text { Przedsiębiorstwo produkcji podstawowej: jego celem jest realizacja zadań, dla } \\
\text { których przedsiębiorstwo zostało powołane. } \\
\text { Przedsiębiorstwo produkcji pomocniczej: wspomaga realizację produkcji } \\
\text { podstawowej. }\end{array}$ \\
\hline $\begin{array}{l}\text { Statystyczno- } \\
\text {-ekonomiczne }\end{array}$ & $\begin{array}{l}\text { Przedsiębiorstwo produkcji towarowej - przeznacza na sprzedaż produkty } \\
\text { wytworzone w przedsiębiorstwie. } \\
\text { Przedsiębiorstwo produkcji globalnej (w analizowanym okresie) - zajmuje się } \\
\text { produkcją towarową plus różnicą stanu produkcji niezakończonej (na koniec } \\
\text { okresu, w stosunku do stanu z początku okresu). } \\
\text { Przedsiębiorstwo produkcji czystej, produkcji własnej, czyli części produkcji } \\
\text { globalnej pozostającej po odjęciu kosztów materialnych tej produkcji. } \\
\text { Przedsiębiorstwo produkcji niezakończonej, czyli zasobów, które (na podsta- } \\
\text { wie dokumentacji) zostały wydane do produkcji z magazynów zaopatrzenio- } \\
\text { wych, ale nie zostały przekazane do magazynów produktów gotowych lub } \\
\text { półfabrykatów. } \\
\text { Przedsiębiorstwo, zajmujące się produkcją w toku, czyli produktami pracy } \\
\text { znajdującymi się w toku procesu technologicznego. }\end{array}$ \\
\hline Złożoność & $\begin{array}{l}\text { Przedsiębiorstwo produkcji prostej - ich celem jest wytworzenie produktów } \\
\text { gotowych. Odbywa się to w toku jednego nieprzerwanego procesu technolo- } \\
\text { gicznego (np. wytwarzanie energii elektrycznej). } \\
\text { Przedsiębiorstwo produkcji złożonej - proces wytwórczy ze względów tech- } \\
\text { nicznych podzielony jest na następujące po sobie fazy (zwykle odpowiadające } \\
\text { rodzajom obróbki); powstałe w ten sposób elementy łączone są ze sobą } \\
\text { w fazie montażu. }\end{array}$ \\
\hline
\end{tabular}

\footnotetext{
${ }^{5}$ Raport o stanie sektora matych i średnich przedsiębiorstw w Polsce, Warszawa 2010, s. 23-29.

${ }^{6}$ H. Bieniok (red.), Przedsiębiorczość, konkurencyjność oraz kondycja..., s. 163.

${ }^{7}$ http://www.egospodarka.pl/38169,Produkcja-w-Polsce (dostęp 30.03.2018 r.).
} 
Tabela 1 (cd.). Typy przedsiębiorstw produkcyjnych

\begin{tabular}{|c|c|}
\hline Kryterium & Rodzaje \\
\hline Liczebność & $\begin{array}{l}\text { Przedsiębiorstwo produkcji jednostkowej - liczba wykonywanych jednorazo- } \\
\text { wo wyrobów nie przekracza kilku sztuk, zwykle na zamówienie (nie „na } \\
\text { skład”); obejmuje duży asortyment o niewielkiej powtarzalności. } \\
\text { Przedsiębiorstwo produkcji seryjnej - wytwarzanie określonej liczby (serii) } \\
\text { jednakowych wyrobów według takiej samej technologii; zależnie od liczby } \\
\text { wyrobów w serii (przy czym „,seryjność jest pojęciem umownym; kilka } \\
\text { gwoździków to nie seria, lecz produkcja jednostkowa, kilka statków pełno- } \\
\text { morskich to wielka seria) wyróżniane są: } \\
\text { - przedsiębiorstwo produkcji małoseryjnej, } \\
\text { - przedsiębiorstwo produkcji średnioseryjneje } \\
\text { - przedsiębiorstwo produkcji wielkoseryjnej, } \\
\text { - przedsiębiorstwo produkcji masowej - wyrób (zwykle w kilku warian- } \\
\text { tach konstrukcyjnych) wytwarzany w ciągu długiego okresu. }\end{array}$ \\
\hline Skala & $\begin{array}{l}\text { Przedsiębiorstwo produkcji przemysłowej. } \\
\text { Przedsiębiorstwo drobnej wytwórczości. } \\
\text { Przedsiębiorstwo produkcji rzemieślniczej. } \\
\text { Przedsiębiorstwo produkcji chałupniczej. }\end{array}$ \\
\hline $\begin{array}{l}\text { Organizacja } \\
\text { pracy }\end{array}$ & $\begin{array}{l}\text { Przedsiębiorstwo produkcji „gniazdowej” }- \text { wytwarzanie odbywa się } \\
\text { w ,gniazdach” - komórkach organizacyjnych wyspecjalizowanych technolo- } \\
\text { gicznie, czyli wykonujących pewien rodzaj obróbki lub przedmiotowo, czyli } \\
\text { wykonujących pewną grupę wyrobów lub ich elementów (detali). } \\
\text { Przedsiębiorstwo produkcji potokowej, produkcji przepływowej (,,potok } \\
\text { produkcyjny”) - stanowiska robocze rozmieszczone są zgodnie z przebiegiem } \\
\text { procesu technologicznego; przetwarzany materiał przemieszcza się w sposób } \\
\text { ciągły od stanowiska do stanowiska. }\end{array}$ \\
\hline $\begin{array}{l}\text { Ciągłość wytwa- } \\
\text { rzania }\end{array}$ & $\begin{array}{l}\text { Przedsiębiorstwo produkcji wsadowej, produkcji w partiach - produkcja } \\
\text { „przerywana”- wytwarzanie produktów w partiach, nieciągły tok produkcji. } \\
\text { Przedsiębiorstwo produkcji ciągłej - produkcja o przepływie ciągłym - prze- } \\
\text { pływ materiału w procesie produkcyjnym jest ciągły (szczególnymi przykła- } \\
\text { dami produkcji ciągłej są procesy chemiczne, metalurgiczne itp.). }\end{array}$ \\
\hline $\begin{array}{l}\text { Rodzaj produk- } \\
\text { tów }\end{array}$ & $\begin{array}{l}\text { Przedsiębiorstwo produkcji dyskretnej, wytwarzanie dyskretne - produkcja } \\
\text { wyróżniających się jednostek wyrobów (np. samochody, artykuły gospodar- } \\
\text { stwa domowego). } \\
\text { Przedsiębiorstwo produkcji procesowej - produkcja, w której mają zastoso- } \\
\text { wanie technologie procesów ciągłych. }\end{array}$ \\
\hline Asortyment & $\begin{array}{l}\text { Przedsiębiorstwo produkcji sprzężonej - przez zastosowanie dodatkowych } \\
\text { komponentów wytwarzanie równocześnie z produktem głównym innego } \\
\text { produktu w celu zwiększenia opłacalności procesu. } \\
\text { Przedsiębiorstwo produkcji ubocznej - wytwarzanie dodatkowych, nietypo- } \\
\text { wych dla przedsiębiorstwa produktów (zob. produkt uboczny), w celu pełniej- } \\
\text { szego wykorzystania posiadanych mocy i środków. } \\
\text { Przedsiębiorstwo produkcji wielowariantowej - wytwarzanie szeregu różnych } \\
\text { produktów w ilościach zgodnie z popytem (możliwościami sprzedaży). }\end{array}$ \\
\hline
\end{tabular}

Źródło: opracowanie własne na podstawie: http://www.egospodarka.pl/38169,Produkcja-w-Polsce (dostęp 30.03.2018 r.). 
Warto określić także cechy małych firm produkcyjnych. Są to: połączenie własności z zarządzaniem, działalność produkcyjna na niewielką skalę i często przy pomocy nie najnowocześniejszych rozwiązań, uruchomienie firmy głównie własnym kapitałem. Motyw założenia takiej działalności to często zapewnienie bytu rodzinie, niska skłonność inwestycyjna, niedopuszczanie zewnętrznych inwestorów, występowanie prostych struktur organizacyjnych.

\section{BARIERY ROZWOJU MAŁEJ FIRMY PRODUKCYJNEJ}

Ustalenie barier hamujących rozwój małych firm produkcyjnych jest działaniem koniecznym w celu określenia dróg prowadzących do ich eliminacji. Literatura przedmiotu podaje i analizuje wiele czynników determinujących rozwój takich firm. Wyniki szeroko prowadzonych badań umożliwiają zestawienie listy podstawowych czynników determinujących rozwój małych firm.

Ł. Sułkowski wymienia następujące bariery rozwoju rodzinnych, małych firm, w tym firm produkcyjnych ${ }^{8}$ : bariery kapitałowe, bariery konkurencyjne, bariery prawne, bariery kosztowe, bariery kompetencyjne, bariery psychologiczne, bariery społeczno-kulturowe. Dokładne wyszczególnienie tych barier pokazuje tabela 2 .

Tabela 2. Identyfikacja barier rozwoju rodzinnych, małych firm produkcyjnych

\begin{tabular}{|l|l|}
\hline \multicolumn{1}{|c|}{ Rodzaj bariery } & \multicolumn{1}{c|}{ Kluczowe kwestie } \\
\hline Bariery kapitałowe & $\begin{array}{l}\text { Brak kapitału na rozwój produkcji przemysłowej. } \\
\text { Wysokie koszty kredytów. } \\
\text { Brak dostępu do źródeł kapitału. }\end{array}$ \\
\hline Bariery konkurencyjne & $\begin{array}{l}\text { Obniżenie się popytu na usługi produkcyjne. } \\
\text { Wzrost konkurencyjności w sektorze. } \\
\text { Agresywna konkurencja w sektorze produkcji. }\end{array}$ \\
\hline Bariery prawne & $\begin{array}{l}\text { Nierówność wobec prawa - małe podmioty są upośledzone. } \\
\text { Zbytnia złożoność prawa. } \\
\text { Zbyt absorbujące i niejasne procedury podatkowe i ubezpieczeniowe. }\end{array}$ \\
\hline Bariery kosztowe & $\begin{array}{l}\text { Wysokie obciążenia podatkowe. } \\
\text { Wysokie obciążenia kosztów pracy. } \\
\text { Wysokie koszty kredytów. } \\
\text { Ogólny wzrost kosztów działalności. }\end{array}$ \\
\hline Bariery kompetencyjne & $\begin{array}{l}\text { Brak kompetentnych pracowników na rynku pracy. } \\
\text { Niekompetentne osoby z rodziny na wysokich stanowiskach (podmioty } \\
\text { rodzinne). } \\
\text { Wysoka rotacja kompetentnych pracowników z poza rodziny (podmio- } \\
\text { ty rodzinne). }\end{array}$ \\
\hline Bariery psychologiczne & $\begin{array}{l}\text { Słaba motywacja i lojalność pracowników. } \\
\text { Mała przedsiębiorczość }\end{array}$ \\
\hline $\begin{array}{l}\text { Bariery społeczno- } \\
\text {-kulturowe }\end{array}$ & $\begin{array}{l}\text { Poczucie niestabilności zatrudnienia. } \\
\text { Mała konkurencyjność wewnętrzna. } \\
\text { Nepotyzm - niesprawiedliwe zasady selekcji i motywowania pracow- } \\
\text { ników. } \\
\text { Korupcja. }\end{array}$ \\
\hline
\end{tabular}

Źródło: Ł. Sułkowski, Bariery rozwoju..., s. 444-445.

${ }^{8}$ Ł. Sułkowski, Bariery rozwoju przedsiębiorstw rodzinnych, Katowice 2003, s. 444. 
Nieco inną klasyfikację barier rozwoju małych firm (w tym produkcyjnych) proponuje M. Dmowski. Na podstawie badań przeprowadzonych przez Deutsche Bank AG przedstawił główne bariery rozwoju małych firm (w tym produkcyjnych) ${ }^{9}$ : brak kapitału oraz nieodpowiednie planowanie finansowe, niedostateczne kwalifikacje, niedobór informacji, przecenienie możliwości zysku.

W. Piątkowski proponuje inne zestawienie. Opierając się na opiniach przedsiębiorców wymienia główne barier rozwoju małych firm, w tym produkcyjnych, w następujący sposób ${ }^{10}$ : brak kapitału, wysokie podatki, ograniczenia prawno-administracyjne, brak środków pomocowych, brak pomocy ze strony lobby, niedostateczny popyt, brak wykwalifikowanych pracowników, problemy z kontrahentami, nieściągalność długów.

M. Starczewska-Krzysztoszek grupuje te czynniki następująco ${ }^{11}$ : pozapłacowe koszty pracy, brak przejrzystości, jednoznaczności, podatków pośrednich (VAT), brak przejrzystości systemu podatku dochodowego od działalności gospodarczej, nieelastyczne prawo pracy, brak wykwalifikowanych pracowników, procedury administracyjne, konkurencja ze strony uprzywilejowanych przedsiębiorstw.

Można więc podsumować, że małe firmy produkcyjne, pomimo istotnego znaczenia dla polskiej gospodarki borykają się z wieloma problemami. Według autora niniejszego artykułu, najistotniejsze to: niemożność sprostania konkurencji ze strony dużych firm produkcyjnych, brak środków finansowych na dalszy rozwój, przestarzałe technologie, tak ważne dla właściwego i nowoczesnego procesu produkcji, niewykwalifikowany dostatecznie personel firm.

\section{SPOSOBY OGRANICZANIA BARIER DETERMINUJĄCYCH ROZWÓJ MAŁEJ FIRMY PRODUKCYJNEJ}

Dla rozwoju małych przedsiębiorstw produkcyjnych niezbędna jest dobra współpraca władz lokalnych z niewielkimi podmiotami. Wynika to przede wszystkim z faktu, że zarówno małe firmy produkcyjne, jak i władze lokalne w znacznym stopniu wpływają na rozwój regionu, jednak na innych płaszczyznach. Władze lokalne powinny więc umożliwić stworzenie odpowiednich warunków rozwoju działalności produkcyjnej, walkę z wszelkimi barierami, szczególnie administracyjnymi i przyciągnięcie inwestorów ${ }^{12}$.

Istnieje zależność między zaangażowaniem władz lokalnych a poziomem aktywności omawianych firm w regionie. Niewielkie podmioty (w tym o profilu produkcyjnym) pobudzają władze samorządowe do działania na rzecz rozwoju regionu. Dążąc do rozwoju własnej działalności są zmuszone współpracować z przedstawicielami samorządu lokalnego. Efekty tej współpracy mają wpływ na rozwój pojedynczej firmy, w rezultacie w końcu stanu gospodarczego całego regionu. Postawa małego przedsiębiorstwa nierzadko wymusza odpowiednie decyzje władz lokalnych. Dążą one przede wszystkim do zapewnienia odpowiedniej infrastruktury koniecznej przy prowadzeniu działalności produkcyjnej. Aktywna działalność samorządu lokalnego i regionalnego w kierunku rozwoju

\footnotetext{
9 Z. Dmowski, E. Gostomski, L. Śledź, Mate i średnie firmy we Wspólnocie Europejskiej i możliwości ich wspótpracy z Polska, Warszawa 1992, s. 23.

${ }^{10}$ W. Piątkowski, Bariery rozwoju małych i średnich przedsiębiorstw, Łódź 2009, s. 3.

${ }^{11}$ M. Starczewska-Krzysztoszek, Bariery rozwoju matych przedsiębiorstw w Polsce, „Indos Zagadnienia Społeczno-Gospodarcze" 2008, nr 2, s. 4.

12 A. Barcik, R. Barcik (red.), Rozwój lokalny i regionalny, Bielsko-Biała 2005, s. 158.
} 
przedsiębiorczości zachęca takie firmy do rozpoczynania działalności w takich miej$\operatorname{scach}^{13}$.

Władze lokalne i regionalne muszą wspierać prowadzenie i rozwój działalności przez omawiane firmy na ich terenie. Chodzi także o dostrzeżenie przez władze lokalne cech jakościowych takich firm. Władze powinny podjąć walkę z takimi problemami jak: utrudniony dostęp do kapitałów obcych, brak dostatecznej informacji, prowadzenie działalności bez zatrudniania specjalistów, brak wiedzy na temat możliwości rozwoju działalności ${ }^{14}$.

Działania władz lokalnych w odniesieniu do małych firm produkcyjnych powinny obejmować następujące obszary ${ }^{15}$ :

1. Zapewnienie odpowiedniej infrastruktury do prowadzenia działalności produkcyjnej. Czynnik ten stanowi podstawowe zadanie władz lokalnych, jest także niezbędnym warunkiem rozwoju działalności produkcyjnej w regionie.

2. Ułatwianie małym firmom produkcyjnym dostępu do pomocy państwa i pomocy ze środków Unii Europejskiej. Skorzystanie z pomocy budżetowej i unijnej wymaga od małych podmiotów sporządzenia odpowiednich dokumentów, wypełnienia wniosków, przedstawienia business planów. Czynności te są dla takich firm wysoce skomplikowane, najczęściej sami nie mają możliwości sprostania tym wymogom. W tym celu władze lokalne powinny organizować kursy, szkolenia poświęcone tym zagadnieniom.

3. Ułatwianie małym firmom dostępu do pomocy z funduszy pożyczkowych, funduszy poręczeniowych, funduszy venture capital. Fundusze te wspierają finansowo niewielkie podmioty. Władze lokalne powinny zabiegać o usytuowanie oddziałów tych funduszy na terenie regionu.

4. Organizacja szkoleń, mających dostarczyć wiedzę na temat nowoczesnych rozwiązań w zakresie prowadzenia firmy produkcyjnej, możliwości zdobycia kapitałów obcych, dostępu do rynków zagranicznych, reklamy.

5. Udzielenie zwolnień podatkowych o charakterze gospodarczym.

6. Kolejną bardzo ważną szansą dla małych firm (w tym produkcyjnych) jest Internet. Wirtualny świat nie wymaga wielkich inwestycji, a stwarza wielkie możliwości. Daje szansę konkurowania z wielkimi firmami. Dlatego też należy położyć nacisk na szkolenie pracowników małych firm w wykorzystaniu Internetu. Dotyczy to zwłaszcza obszaru promocji, która to w tradycyjnej formie jest związana z ogromnymi kosztami ${ }^{16}$.

Tradycyjne modele biznesu stają się przestarzałe, firmy zaś w celu sprostania współczesnym wyzwaniom konkurencyjnym zmuszane są do szukania nowych rozwiązań. Najczęściej sprowadza się to do przyjmowania nowych form organizacyjnych biznesu, które charakteryzują się luźnymi powiązaniami pomiędzy firmami oraz półprzenikalnymi granicami. W literaturze przedmiotu owe luźno powiązane formy organizacyjne nazywane są zamiennie ,organizacjami wirtualnymi”, ,organizacjami sieciowymi” lub „organiza-

\footnotetext{
13 Tamże, s. 159.

${ }^{14}$ E. Bończak-Kucharczyk, K. Herbst, K. Chmura, Jak wtadze lokalne moga wspierać przedsiębiorczość, Warszawa 2000, s. 17

${ }^{15}$ H. Bieniok (red.), Przedsiębiorczość, konkurencyjność oraz kondycja..., s. 163.

16 Tamże.
} 
cjami modularnymi" ${ }^{17}$. Organizacja wirtualna jest dynamicznym narzędziem zarządzania. Opiera się na sieciach komputerowych i możliwościach korzystania z banków informacyjnych takich jak Internet, który jest idealnym środkiem ułatwiającym osiąganie przewagi konkurencyjnej na rynku globalnym. Sieć organizacyjna stanowiąca podstawę kreowania organizacji wirtualnej jest zazwyczaj nieograniczonym zbiorem partnerów, którzy zaakceptowali podstawowe cele i zasady tejże organizacji. Organizacja wirtualna to połączenie dziesiątek, a nawet setek firm, przy czym każda z nich skupiona jest na tym rodzaju działalności, który wykonuje najlepiej, oraz wszystkie są połączone elektroniczną siecią, tak że pracują jako jedna całość - elastycznie i przy niższych kosztach - bez względu na swoją lokalizację ${ }^{18}$.

Dzięki organizacjom wirtualnym możliwe staje się przekraczanie granic przestrzennych i granic czasu w tworzeniu sieci dostawców usług, omijanie barier politycznych, socjokulturowych i technologicznych; tworzenie efektywnych instrumentów pozyskiwania, analizy i przetwarzania informacji w procesach decyzyjnych przedsiębiorstw; wzmocnienie rzeczywistych powiązań biznesowych pomiędzy centrum i siecią, zwiększenie efektu synergii sieciowej formy organizacji oraz przenoszenie całości lub części działań biznesowych z otoczenia rzeczywistego w przestrzeń otoczenia komunikacyjnego. Niezwykła dynamika zmian otoczenia komunikacyjnego kreuje nowe szanse rozwoju wirtualnych form organizacji. Wzrasta bowiem liczba i różnorodność wirtualnych przedsiębiorstw działających tylko w przestrzeni otoczenia komunikacyjnego ${ }^{19}$.

Dzięki takim organizacjom w warunkach gospodarki informacyjnej możliwe staje się istnienie rynków bez firm, co jest zgodne z teorią ekonomii instytucjonalnej. Zanik asymetrii w zakresie informacji osłabia bardzo lub wręcz czyni bezprzedmiotową krytykę tego założenia. Nieistnienie firm implikuje brak produkcji, a to z kolei niemożność występowania rynków, bo rynki niemające żadnej funkcji do spełnienia nie istnieją. Funkcje rynków ulegają w gospodarce informacyjnej znacznemu poszerzeniu, co daje podstawę do istnienia firm. Tyle tylko, że firmy nie organizują się dłużej w formie koordynowanej administracyjnie regulacji hierarchicznej. W erze informacyjnej, to nie - jak zakłada ekonomia instytucjonalna - pionowo zintegrowane firmy wypierają rynki, a odwrotnie, rynkowe mechanizmy regulacji gwałtownie wypychają mechanizmy regulacji oparte na hie$\operatorname{rarchii}^{20}$.

\section{ANALIZA BARIER I SPOSOBÓW ICH PRZEZWYCIĘŻANIA MAŁEJ FIRMY PRODUKCYJNEJ NA PRZYKŁADZIE PRZEDSIĘBIORSTWA PRO-ART}

Firma PRO-ART jest małą firmą produkcyjną, która wciąż się rozwija. To przykład firmy, która pomimo problemów, charakterystycznych dla tej grupy przedsiębiorstw, nadal trwa i dba o swój rozwój. Firma ta charakteryzuje się wysokiej jakości wyrobami przemysłowymi, dbałością o klienta. Produkuje także na zlecenie, czyli pod konkretne zamówienie klienta. Ważne też jest to, że na wszystkich etapach produkcji odbywa się

\footnotetext{
${ }^{17}$ M. Alexander, Getting to Grips with the Virtual Organization, „Long Range Planning” 2010, No. 30 , s. 2.

${ }_{18}$ W.M. Grudzewski, I.K. Hejduk, Przedsiębiorstwo wirtualne, Warszawa 2002, s. 39

19 Tamże.

${ }^{20}$ Skawińska E. (red.), Konkurencyjność przedsiębiorstw - nowe podejście, Warszawa-Poznań 2002, s. 41.
} 
kontrola jakości. Mimo ograniczeń firma funkcjonuje, a ponadto wciąż wprowadzane są nowe inwestycje.

W trakcie zbierania materiałów do niniejszego opracowania autorzy przeprowadzili wywiady z kierownictwem firmy, co pozwoliło zidentyfikować czynniki, które determinowały rozwój firmy. Kierownictwo przyznało, że najważniejszą i najbardziej dotkliwą barierą rozwoju firmy, było bariera finansowa. Przyznało ono także, że majątkiem na rozpoczęcie działalności były ich własne oszczędności. Bariery kapitałowe w firmie w ujęciu procentowym przedstawiały się następująco: brak kapitału na rozwój produkcji przemysłowej, wysokie koszty kredytów, brak dostępu do źródeł kapitału. Sytuację tę przedstawia rys. 1 .

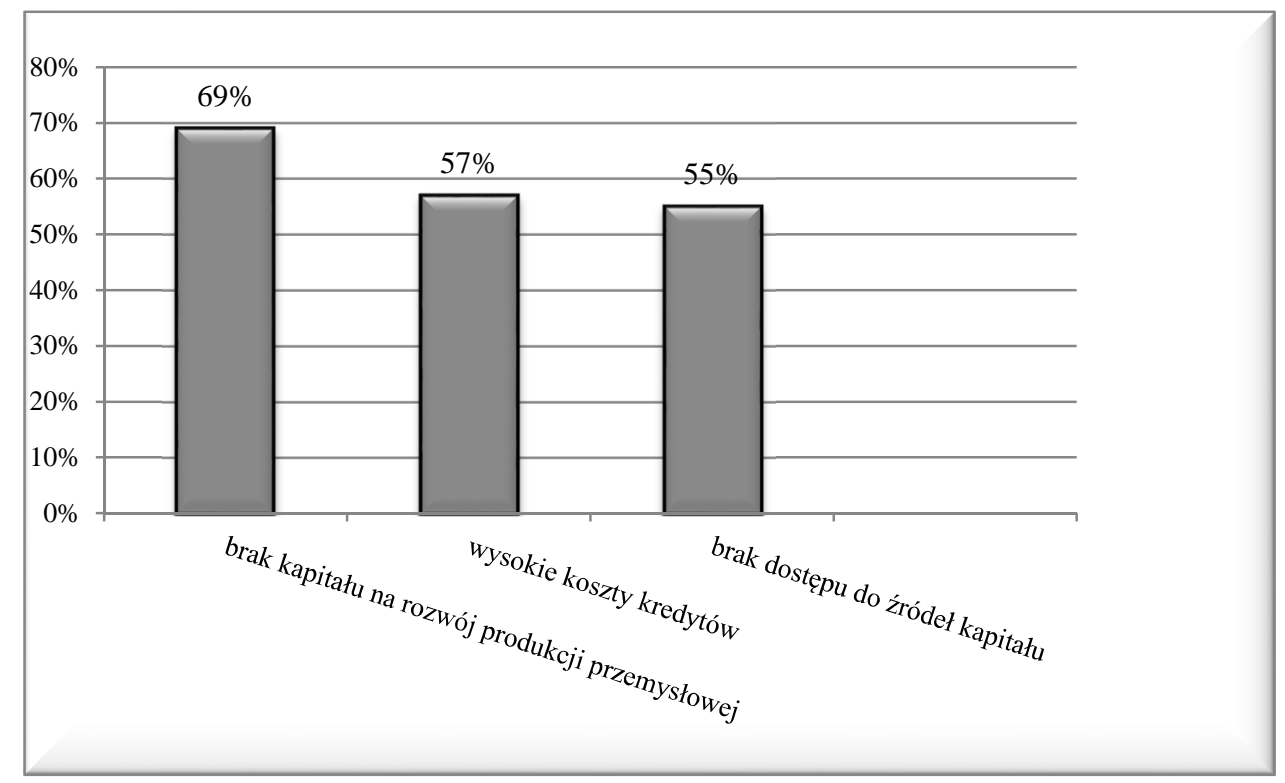

Rys. 1. Bariery kapitałowe

Źródło: opracowanie własne na podstawie przeprowadzonych badań.

Kierownictwo narzekało też na niestabilność regulacji prawnych. Dużą trudnością były zmiany przepisów, co uniemożliwiało firmie przewidywanie i planowanie działalności. Dal pracowników PRO-ART, interpretacja wchodzących w życie aktów prawnych była bardzo trudna, nie rozumieli oni ich treści. Kierownictwo firmy skarżyło się te na ograniczenia administracyjne związane z podejmowaniem działalności gospodarczej.

Autorzy artykułu nazwali powyższe trudności ,,barierami prawnymi”. Poproszono kierownictwo firmy o procentowe wskazanie uciążliwości tych czynników. Wyniki były następujące: zbytnia złożoność prawa (50\%), nierówność wobec prawa - małych i dużych podmiotów (30\%), zbyt absorbujące i niejasne procedury podatkowe i ubezpieczeniowe $(20 \%)$. 
Kierownictwo wymieniło też bariery kosztowe, jak i pogrupowało je nadając im wskaźniki procentowe, oddając w ten sposób rangę ,,uciążliwości” dla firmy. Pokazuje to rys. 2.

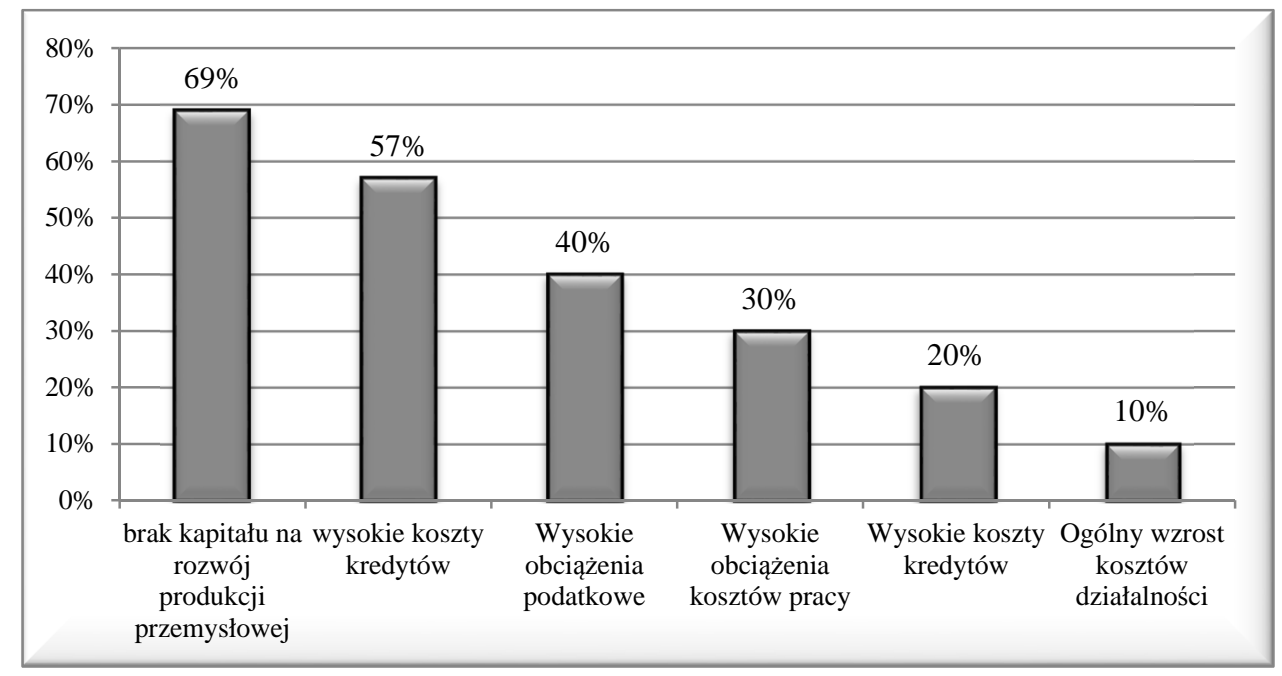

Rys. 2. Bariery kosztowe

Źródło: opracowanie własne na podstawie przeprowadzonych badań.

Wśród barier ograniczających rozwój firmy znalazła się duża konkurencja ze strony dużych firm produkcyjnych, w tym podmiotów zagranicznych. Dużym problemem na początku działania firmy było zacofanie technologiczne i niska jakość procesu produkcji. Firma dysponowała przestarzałym parkiem maszynowym. Problem pojawił się również, kiedy firma PRO-ART zaczęła się ubiegać o kredyt bankowy. Firma nie potrafiła udokumentować relatywnie swojej „długiej historii trwania” i miała wrażenie, że jawi się bankowi jako „obcy”. Zatrudnieni w firmie nie potrafili znaleźć instrukcji, jak właściwie wypełnić wniosek o kredyt. Nie potrafili też opracować biznesplanu. W końcu firma zrezygnowała z ubiegania się o ten kredyt. Stanowiło to dużą stratę dla przedsiębiorstwa.

Firma PRO-ART nie uzyskała również wsparcie od władz lokalnych. Niestety, firma nie słyszała o żadnych szkoleniach czy doradztwie dla małych firm. Nikt w urzędzie miasta nie potrafił dostatecznie wyjaśnić, gdzie można otrzymać pomoc finansową dla takich firm. Należy też zaznaczyć, że firma wciąż obawia się skutków kryzysu gospodarczego, a co za tym idzie - obniżonego popytu na wyroby firmy.

Podczas wywiadu z pracownikami firmy, kierownictwo firmy podkreśliło także inne ważne czynniki, działające na niekorzyść firmy. Są to: wzrost konkurencyjności w sektorze, agresywna konkurencja w sektorze produkcji, brak przejrzystości, jednoznaczności podatków pośrednich (VAT), niska jakość procesu produkcji, niedostatecznie wykwalifikowani pracownicy. Pracownicy nadali tym problemom wskaźniki procentowe, oddając w ten sposób rangę ,uciążliwości” dla firmy. Sytuację tę pokazuje rys. 3. 


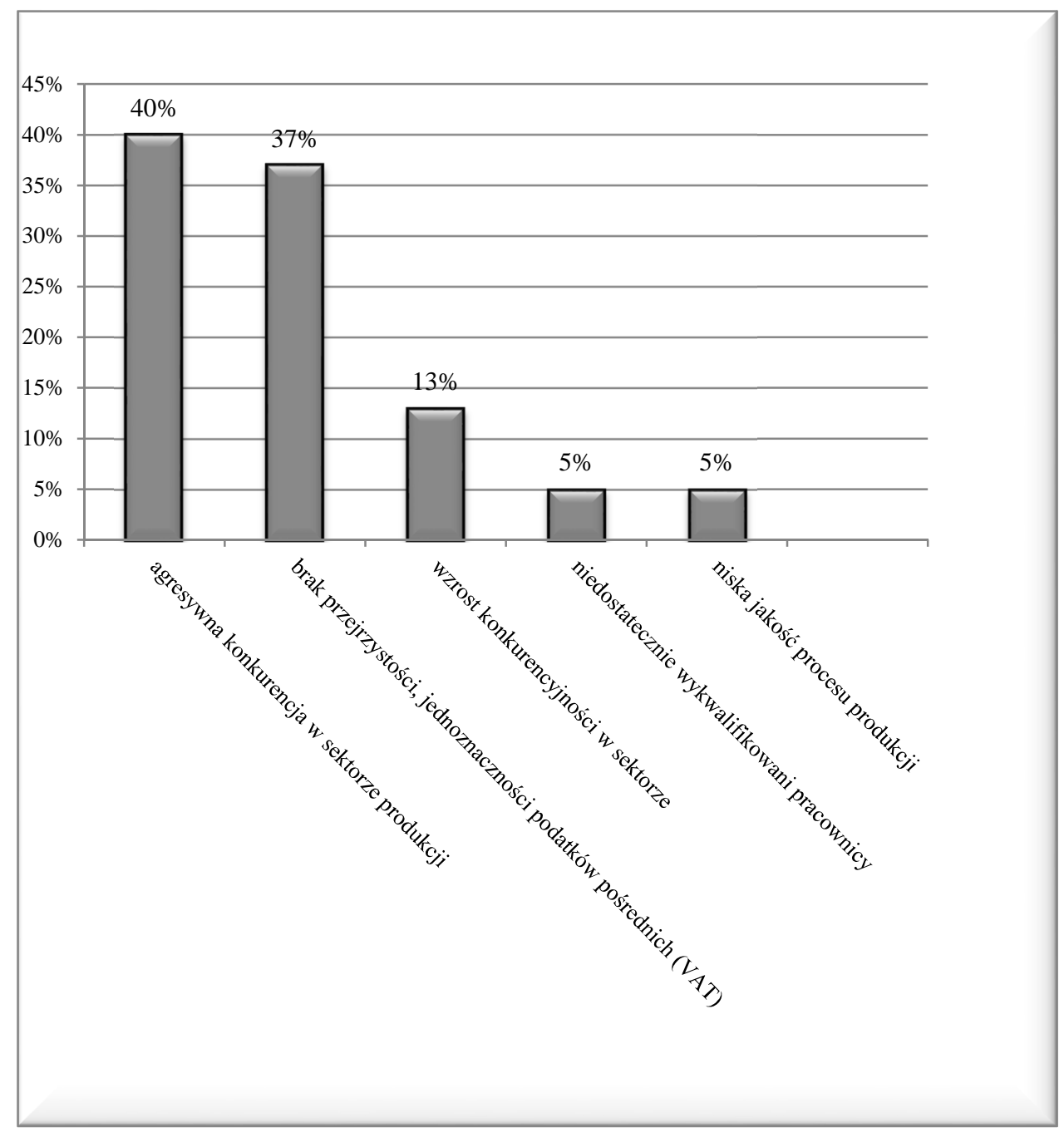

Rys. 3. Czynniki działające na niekorzyść firmy

Źródło: opracowanie własne na podstawie przeprowadzonych badań.

Można wiec stwierdzić, że firma borykała się z wieloma problemami, zresztą bardzo charakterystycznymi dla czynników niekorzystnych dla małych firm. Pomimo tych trudności firma funkcjonowała dalej, rozwijała się, dbała o wysoki poziom jakości, aż wreszcie rozszerzyła swój zakres działania, stając się dużą firmą produkcyjną. Na tej podstawie warto prześledzić metody walki firmy PRO-ART z omówionymi barierami.

Firma PRO-ART podjęła wszelkie wysiłki, aby być bardziej konkurencyjną. Autorzy niniejszej pracy dokonali analizy tych czynników, które stały się skutecznym sposobem walki z barierami. Firma PRO-ART była uczestnikiem szkolenia organizowanego przez 
PARP. Na tym bezpłatnym szkoleniu firma dowiedziała się o możliwościach pozyskiwania funduszy z Unii Europejskiej. Pozyskała także umiejętność pisania biznesplanów.

Przedsiębiorstwo doceniło także rolę Internetu, dlatego zadbało o stworzenie własnej strony internetowej. Zamówień można w firmie dokonywać przez Internet. Przedsiębiorstwo korzysta również z dobrodziejstw outsourcingu. Zatrudniło bowiem ekspertów zewnętrznych z dziedziny IT, księgowości, marketingu i zewnętrznych dostawców. Udział poszczególnych rodzajów outsourcingu w strukturze wewnętrznej firmy pokazuje rys. 4.

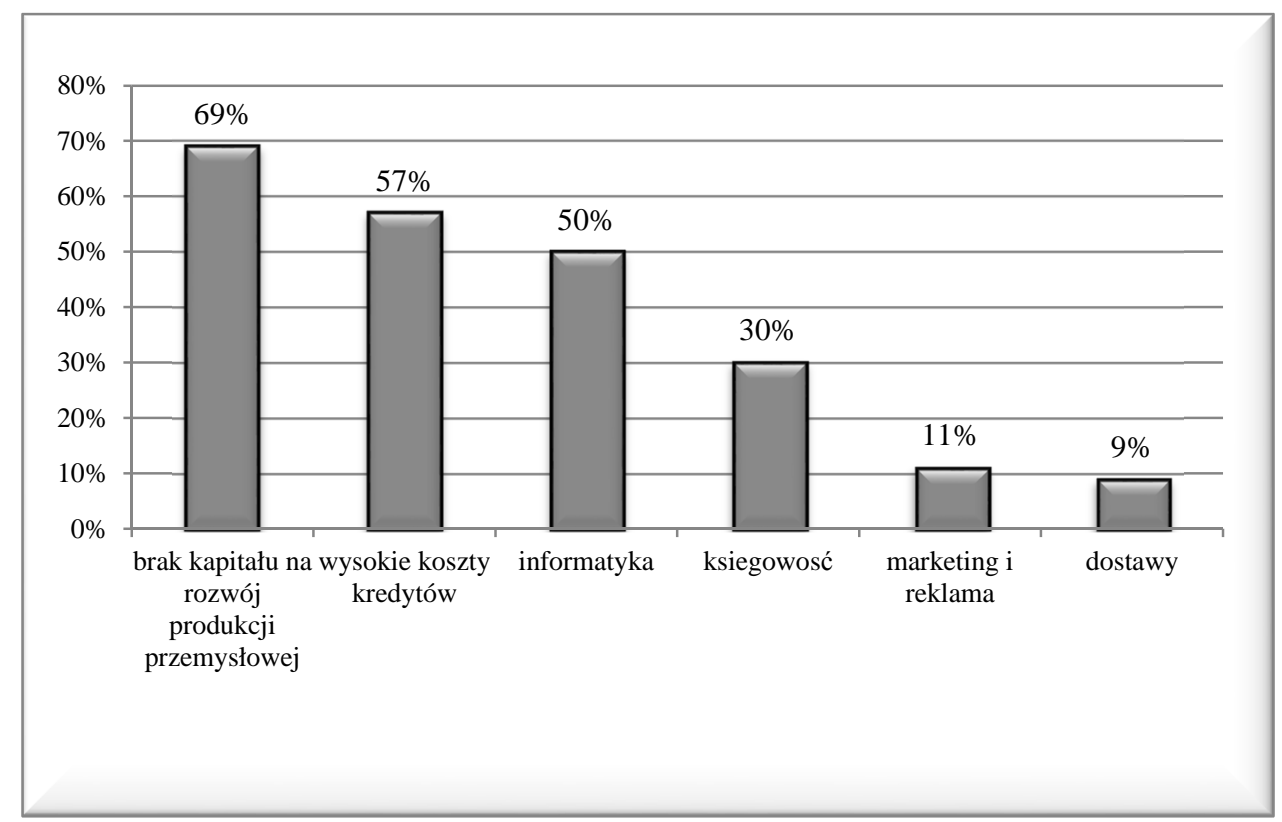

Rys. 4. Udział poszczególnych rodzajów outsourcingu w strukturze wewnętrznej firmy (w \%)

Źródło: opracowanie własne na podstawie przeprowadzonych badań

Firma PRO-ART uwzględnia outsourcing w strategii firmy. Kierownictwo firmy pokazało autorom wywiadu, które z funkcji przedsiębiorstwa są obecnie wydzielane, które będą wydzielane w najbliższej przyszłości, a które wcale. Dane te dotyczą działu finansów i księgowości. Funkcje te pokazuje tabela 3.

Przedsiębiorstwo ma także zamiar aplikować o pomoc finansową z Unii Europejskiej. Pracownicy firmy zdają sobie sprawę z tego, jak ważne są dotacje i jak duża jest ich rola $\mathrm{w}$ finansowaniu inwestycji, tak istotnych dla firmy produkcyjnej. Ich koszt realizacji jest znacznie niższy w przypadku korzystania z środków unijnych, niż przy korzystaniu z innych źródeł, np. kredytu bankowego. Dotychczas źródłem finansowania firmy PRO-ART były przede wszystkim środki własne i zobowiązania wobec dostawców. Sytuację tę pokazuje rys. 5 . 
Tabela 3. Wydzielane funkcje finansów i księgowości z firmy PRO-ART

\begin{tabular}{|l|l|l|l|}
\hline \multicolumn{1}{|c|}{ Funkcje } & \multicolumn{3}{|c|}{ Funkcje cząstkowe } \\
\hline Relacje z inwestorami & Sporządzanie raportów* & Dystrybucja raportów* & Komunikacja* \\
\hline Podatki & $\begin{array}{l}\text { Opracowywanie strategii } \\
\text { podatkowej* }\end{array}$ & $\begin{array}{l}\text { Realizacja strategii } \\
\text { podatkowej* }\end{array}$ & Regulowanie* \\
\hline Audyt & Planowanie* & Wykonywanie* & Rejestrowanie*** \\
\hline Planowanie finansowe & Sporządzanie planów** & Budżetowanie* & Ocena*** \\
\hline Zarządzanie gotówką & $\begin{array}{l}\text { Zdobywanie fundu- } \\
\text { szy*** }\end{array}$ & $\begin{array}{l}\text { Zarządzanie gotów- } \\
\text { ką*** }\end{array}$ & $\begin{array}{l}\text { Zarządzanie ryzy- } \\
\text { kiem** }\end{array}$ \\
\hline Rachunkowość & $\begin{array}{l}\text { Rachunkowość zarząd- } \\
\text { cza*** }\end{array}$ & $\begin{array}{l}\text { Należności } \\
\text { i zobowiązania** }\end{array}$ & Płace* \\
\hline
\end{tabular}

*-dzisiaj ** - w najbliższej przyszłości *** - wcale

Źródło: dane uzyskane z działu księgowości i finansów w firmie PRO-ART.

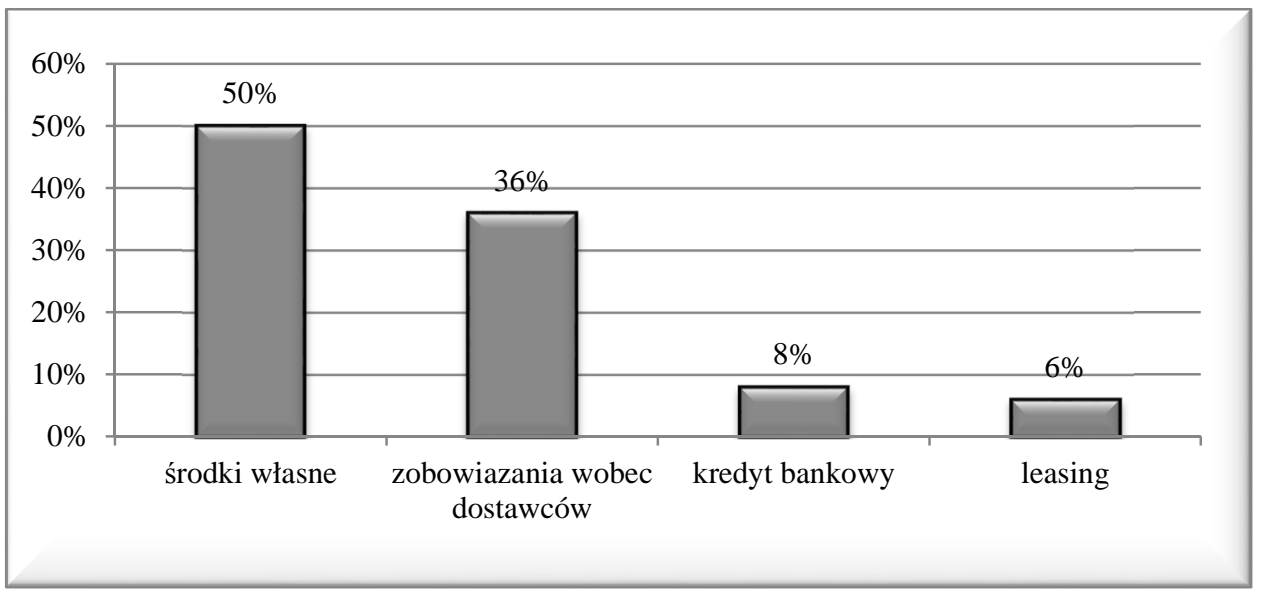

Rys. 5. Źródła finansowania firmy PRO-ART

Źródło: opracowanie własne na podstawie przeprowadzonych badań

Podsumowując można stwierdzić, że firma PRO-ART wciąż poszukuje aktywnych sposobów walki z barierami determinującymi ich rozwój. Optymistyczny jest fakt, że firma wciąż się rozwija, korzysta z dobrodziejstw Internetu. Dostrzega też ogromną szansę, jaka daje pomoc z Unii Europejskiej. Zatrudnia też ekspertów zewnętrznych, a więc stosuje outsourcing.

\section{WNIOSKI KOŃCOWE}

Małe przedsiębiorstwa (w tym produkcyjne) pełnią istotną rolę w gospodarce każdego kraju. Można też stwierdzić, że są one podstawą rozwoju wszystkich współczesnych go- 
spodarek. Ich znaczenie jest ogromne, z uwagi na fakt, że stymulują wzrost gospodarczy poprzez aktywizację procesów innowacyjnych. Poza tym generują nowe miejsca pracy.

W niniejszym artykule dokonano analizy sposobów ograniczania barier determinujących rozwój małej firmy produkcyjnej. Bardzo pomocna okazuje się właściwa współpraca władz lokalnych z małymi podmiotami. Zadania władz lokalnych w tym zakresie sprowadzają się do: zapewnienia odpowiedniej infrastruktury do rozwoju działalności tych firm, pomocy małym firmom produkcyjnym, dostęp do pomocy państwa i wsparcia ze środków Unii Europejskiej, organizowania kursów i szkoleń, w których mały przedsiębiorca nauczy się wypełnienia wniosków, przedstawienia biznesplanów, udzielenia zwolnień podatkowych o charakterze gospodarczym.

Wielką szansą rozwoju małych firm jest Internet. Działalność internetowa nie wymaga dużych inwestycji, a stwarza ogromne możliwości. Możliwe staje się konkurowanie z dużymi przedsiębiorstwami. Jednak, aby skutecznie wykorzystać zalety działalności w wirtualnym świecie, należy położyć nacisk na szkolenie pracowników małych firm w wykorzystaniu Internetu. Dotyczy to głównie sfery promocji, która wiąże się z ogromnymi kosztami

Przedstawiono także ogromną rolę i znaczenie outsourcingu. Jego zalety są niezliczone (koncentracja na problemach strategicznych, zwiększanie swobody strategicznej działalności, zwiększanie skuteczności i efektywności, dostęp do know-how, poprawa pozycji konkurencyjnej, zwiększenie skali działalności, dywersyfikacja lub koncentracja działalności, zwiększenie przychodów, redukcja kosztów itd.).

Ogromną szansę rozwoju małych przedsiębiorstw dają fundusze unijne. Dzięki korzystaniu z nich małe firmy mogą umocnić swoją pozycję konkurencyjną na arenie światowej. Poza tym pozostają ważnym czynnikiem finansowania inwestycji, tak istotnych dla firmy produkcyjnej. Dzięki nim można na przykład zakupić nowoczesną technologię. Należy pamiętać, że małe firmy, w tym produkcyjne mogą starać się o dofinansowanie projektów z różnych dziedzin. Unia Europejska dysponuje ogromnym wachlarzem programów pomocowych.

Inne koncepcje wsparcia małych przedsiębiorstw to: możliwość korzystania $\mathrm{z}$ agencji rozwoju i wspierania MŚP, ośrodków wsparcia przedsiębiorczości, urzędów pracy i wyspecjalizowanych instytucji finansowych.

\section{Literatura}

1. Alexander M., Getting to Grips with the Virtual Organization, „Long Range Planning” 2010, No. 30.

2. Barcik A., Barcik R. (red.), Rozwój lokalny i regionalny, Wyd. ATH w Bielsku-Białej, Bielsko-Biała 2005.

3. Bieniok H. (red.), Przedsiębiorczość, konkurencyjność oraz kondycja matych i średnich przedsiębiorstw w obliczu integracji z Uniq Europejska, Wyd. AE Katowice, Katowice 2003.

4. Bończak-Kucharczyk E., Herbst K., Chmura K., Jak wtadze lokalne moga wspierać przedsiębiorczość, Polska Fundacja Promocji i Rozwoju Małych i Średnich Przedsiębiorstw, Warszawa 2000.

5. Dmowski Z., Gostomski E., Śledź L., Małe i średnie firmy we Wspólnocie Europejskiej i możliwości ich wspótpracy z Polska, Instytut Gospodarki Światowej, PWE, Warszawa 1992. 
6. Grudzewski W.M., Hejduk I.K., Przedsiębiorstwo wirtualne, Wyd. Difin, Warszawa 2002.

7. http://www.egospodarka.pl/38169,Produkcja-w-Polsce.

8. Piątkowski W., Bariery rozwoju matych $i$ średnich przedsiębiorstw, Wydawnictwo Uniwersytetu Łódzkiego, Łódź 2009.

9. Raport o stanie sektora małych i średnich przedsiębiorstw w Polsce, PARP, Warszawa 2010.

10. Skawińska E. (red.), Konkurencyjność przedsiębiorstw - nowe podejście, PWN, Warszawa-Poznań 2002.

11. Starczewska-Krzysztoszek M., Bariery rozwoju małych przedsiębiorstw w Polsce, „Indos - Zagadnienia Społeczno-Gospodarcze" 2008, nr 2.

12. Sułkowski Ł., Bariery rozwoju przedsiębiorstw rodzinnych, Wydawnictwo AE Katowice, Katowice 2003.

\section{ANALYSIS OF WAYS TO REDUCE BARRIERS THAT DETERMINE THE DEVELOPMENT OF A SMALL MANUFACTURING COMPANIES}

Small enterprises contribute to the activation of the workforce for the region. Their role is also to stimulate entrepreneurship and to contribute to reducing the level of unemployment. The activity of such entities influences the emergence of further economic initiatives. The operation of small businesses animates the competitiveness of the region and expands the scope of investments in it. In addition, actions undertaken by small companies remain a source of income for regional budgets that may be allocated to implement developmental objectives of this region. It should also be mentioned that small enterprises (including manufacturing companies described in this article) stimulate local government to undertake pro- developmental actions in the region.

The problem of developmental barriers of small companies, including manufacturing ones, requires more attention and discussion especially facing the current economic problems of Poland. It is necessary to minimize these barriers. The analysis of problems which small businesses face prompts to ask the following questions:

What are the factors determining the development of small companies, including manufacturing companies? How can these barriers be overcome?

However, we must realize that undertaking everything what may be done to overcome these barriers carries many dilemmas, and sometimes also risks. Therefore, the purpose of this article is to analyze ways to reduce barriers that determine the development of a small manufacturing companies. The „Pro-Art” company was used here as an example.

In Poland, there are still few studies focusing on effective ways to eliminate developmental barriers of small enterprises, especially of the production profile. Knowledge about improving these processes is also insufficient.

Keywords: barriers, development, small and medium enterprises.

DOI: $10.7862 /$ rz.2018.mmr.10

Tekst ztożono $w$ redakcji: kwiecień 2018 r.

Tekst przyjęto do druku: kwiecień 2018 r. 
